\title{
Outcome of surgically treated Lisfranc injury: A review of 34 cases
}

\author{
Cerrahi olarak tedavi edilen Lisfranc yaralanmasının sonucu? \\ 34 olgunun değerlendirilmesi
}

Mohd Fairudz Mohd MISWAN, Vivek Ajit SINGH, Nor Faissal YASIN

\section{BACKGROUND}

We reviewed cases with Lisfranc injuries who presented to our center in order to study the adequacy of the treatment method and their final functional outcome.

\section{METHODS}

This is a retrospective review of 34 cases diagnosed with Lisfranc injuries treated at our center from 2000 to 2006. This review is aimed to determine the demography and functional outcome of all patients with Lisfranc injury treated during this period.

\section{RESULTS}

The injury was classified based on the "Hardcastle and Associates Classification". In our review, we found that the commonest Lisfranc injury was type B2 (41\%). These injuries are mostly fixed with K-wires (76.5\%). All patients assessed with Bristol Foot Score (BFS) had a good score in all categories, with a total score ranging from 16 to 25 .

\section{CONCLUSION}

We concluded that all Lisfranc injuries, whether treated with closed or open fixation methods, demonstrated a good long-term functional outcome.

Key Words: Lisfranc injuries; functional outcome.

\section{$\boldsymbol{A M A C}$}

Merkezimize başvuran Lisfranc yaralanması olan olgular, tedavi yöntemi ve nihai fonksiyonel sonuçları incelenerek değerlendirildi.

\section{GEREC VE YÖNTEM}

Bu retrospektif çalışmada, merkezimizde 2000 ile 2006 yılları arasında Lisfarnc yaralanması tanısıyla tedavi edilen 34 olgunun sonuçları değerlendirildi. Bu yazıyla, bu dönemde tedavi edilen Lisfranc yaralanması olan tüm hastaların demografik ve fonksiyonel sonucun belirlenmesi amaçland.

\section{BULGULAR}

Yaralanmalar "Hardcastle ve Arkadaşlarının Sınıflaması"na göre sınıflandırıldı. En yaygın Lisfranc yaralanması tipi, tip B2 (\%41) oldu. Bu yaralanmalar, çoğunlukla K-telleri ile sabitlendi $(\% 76,5)$. Bristol Foot Skoru (BFS) ile değerlendirilen hastalar, 16 ile 25 arasında değişen toplam skor ile bütün kategorilerde iyi bir skora sahipti.

\section{SONUÇ}

İster kapalı ister açık fiksasyon yöntemleri ile tedavi edilsin, bütün Lisfranc yaralanmalarının iyi bir uzun süreli fonksiyonel sonuç gösterdiğini düşünüyoruz.

Anahtar Sözcükler: Lisfranc yaralanmaları; fonksiyonel sonuç.
Fracture dislocation of the tarsometatarsal joint of the foot (Lisfranc injury) is a serious injury. It is rare, with less than $1 \%$ ever reported in the literature. ${ }^{[1-4]}$ However, the true incidence is probably higher and is increasing daily due to the increased number of motor vehicle accidents, industrial accidents and sports injuries. Traumatic tarsometatarsal injuries are usually accompanied by multiple other injuries and may be caused by a high-energy motor vehicle or industrial accident. These injuries can be caused by a direct or indirect mechanism. They normally present as open fractures and are associated with soft tissue injuries, 
such as degloving injuries and bone and cartilage loss.

Isolated Lisfranc injuries are more common in sports injuries and occur as a result of a sudden torque applied to the foot when a portion of it is fixed or by axial loading of the foot in a vertical position. The Lisfranc joint consist of articulation of first and second metatarsal bases with the first and second cuneiform bones. It is held together by the Lisfranc ligament, which is a band of ligamentous tissue that connects the medial cuneiform and the base of the second metatarsal. Thus, the Lisfranc joint is considered the "keystone" of the midfoot due to the wedging of the second metatarsal into the second cuneiform space. The joint is also the focal point of all tarsometatarsal articulation. ${ }^{[3-6]}$

Radiographs taken of the injured foot would reveal an abnormal space between the bases of the first and second metatarsal. This can be easily missed in the Accident and Emergency setting. Failure to recognize this can lead to chronic pain and impairment. ${ }^{[1]}$ A good outcome to this injury depends on accurate anatomical reduction. ${ }^{[1,2,4]}$ Lisfranc injuries are mostly treated with percutaneous K-wire fixation or temporary screw fixation whether using closed or open reduction technique. The reported results are related to the accuracy of reduction and also to the severity of associated articular and soft tissue damage. Conservative casting of the injuries without fixation has not proven to be effective.

We reviewed cases of Lisfranc injuries presenting to our center in order to study the adequacy of the treatment method and their final functional outcome.

\section{MATERIALS AND METHODS}

This was a retrospective study carried out from 1 January 2000 to 31 December 2006. Patients were identified by reviewing the operating theater records. Patients' records were then traced from the records department and the X-rays were traced from the Radiology Department. The radiographs were evaluated by an independent reviewer from the Radiology Department. The radiographs taken at diagnosis and initial follow-up are usually in three views, as anterior-posterior, lateral and oblique. Once the injury had

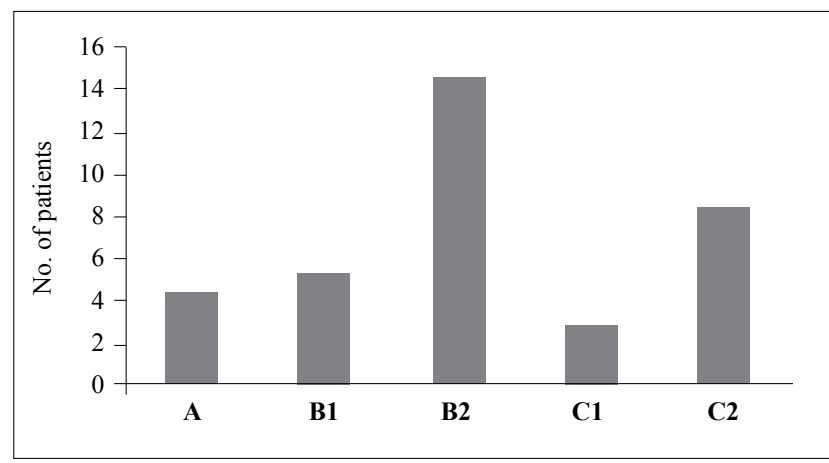

Fig. 1. Distribution of patients according to Hardcastle classification.

healed, weight-bearing stress radiographs were taken to determine any subtle instability. All cases had a radiograph of the affected foot taken at their last followup.

These injuries were classically evaluated with the Hardcastle Classification. ${ }^{[1]}$ We used the Modified Hardcastle Classification $^{[7]}$ for this study (Table 1). Patients were then contacted for further evaluation, and all data were entered in the data collection form. This qualitative assessment was developed based on an evaluation performed using the Bristol Foot Score (BFS) ${ }^{[8]}$ As it is a self-administered assessment, there are no inter-observer variations. The entire questionnaire can be completed within 3 to 5 minutes, encouraging better response levels. It consists of questions regarding the function, i.e. mobility, pain, footwear, foot health, and disability, and self-perception as a result of the foot problems. We also repeated radiographs of the affected foot during the evaluation to study the current status of the injury.

\section{RESULTS}

Over this study, we identified 34 patients with Lisfranc injuries. The majority of the patients were males, with only one female. The average age of our patients was 30 years, with the majority (85\%) between 18 to 45 years old. Two cases were younger than 18 years of age and three were older than 45 years of age. The mean follow-up was 48 months (range: 8-72 months).

These injuries were sustained via motor vehicle ac-

Table 1. Hardcastle classification

Type A (total incongruity)

Type B1 (partial incongruity)

Type B2 (partial incongruity)

Type C1 (divergent/partial displacement)

Type C2 (divergent/total displacement)
All five metatarsals are displaced as a unit.

The first metatarsal is displaced medially with or without displacement of one or more of the other metatarsals.

The first metatarsal remains intact whereas there is lateral displacement of one or more other metatarsals.

The first metatarsal is displaced medially with less than four of the other metatarsals displaced laterally.

The first metatarsal is displaced medially and all the others are displaced laterally. 
cident in 21 cases, industrial accident in 8 and sports injury in 1 ; in 4 cases, they were due to other causes. There was almost equal involvement of both feet (right foot: 18 cases, left foot: 16 cases). There were 20 cases of isolated injury and 14 cases related with polytrauma. Twenty-five patients $(74 \%)$ had closed injuries and $9(26 \%)$ open injuries.

In our series, 4 patients sustained type A injury, 5 type B1, 14 type B2, 3 type $\mathrm{C} 1$, and 8 type $\mathrm{C} 2$ injury, based on Hardcastle Classification (Fig. 1).

All the patients were treated surgically. For closed isolated injuries, the surgery was carried out on an elective basis within two days of injury and for cases of polytrauma, the reduction was done as soon as possible on an emergency basis. There was only one case that was initially treated conservatively by closed manual reduction (conservative), but the post-reduction radiograph showed that there was still displacement and the patient was subsequently stabilized operatively. In
Table 2. Distribution of patients according to type of fixation

Type of fixation No. of patients

Closed reduction \& percutaneous K-wire $\quad 11$

Open reduction \& K-wire fixation

Open reduction \& screw fixation

5

Open reduction with K-wire \& screw fixation

all patients, the operated foot was immobilized in a below-knee back slab for eight weeks postoperatively. After eight weeks, the K-wires were removed and these patients were allowed partial weight-bearing for the subsequent three weeks, followed by full weightbearing.

The methods of fixation used are shown in Table 2, and consisted of close manual reduction with percutaneous K-wire, open reduction with K-wire or screw fixation (as shown in Fig. 2) or both K-wire and screw

Table 3. Patient demographics

\begin{tabular}{|c|c|c|c|c|c|c|c|c|c|}
\hline No & Age & Sex & Etiology & Site & $\begin{array}{l}\text { Nature of } \\
\text { injury }\end{array}$ & $\begin{array}{c}\text { Hardcastle } \\
\text { classification }\end{array}$ & Operation done & BFS & $\begin{array}{l}\text { Isolated of } \\
\text { polytrauma }\end{array}$ \\
\hline 1 & 57 & Male & Fall & Right & Closed & B1 & ORIF, screw \& K-wire & 23 & Isolated \\
\hline 2 & 43 & Male & MVA & Right & Open & B1 & CMR, p/c K-wire & 24 & Polytrauma \\
\hline 3 & 17 & Male & Sports & Right & Closed & $\mathrm{B} 2$ & CMR, p/c K-wire & 20 & Isolated \\
\hline 4 & 24 & Male & Industrial & Left & Closed & B2 & OR \& K-wire & 24 & Isolated \\
\hline 5 & 25 & Male & MVA & Left & Closed & $\mathrm{C} 2$ & OR \& K-wire & 25 & Isolated \\
\hline 6 & 55 & Male & MVA & Right & Closed & B2 & ORIF \& screw fix & 24 & Isolated \\
\hline 7 & 18 & Male & MVA & Left & Closed & B2 & CMR, p/c K-wire & 15 & Polytrauma \\
\hline 8 & 27 & Male & MVA & Right & Open & $\mathrm{B} 2$ & OR \& K-wire & 24 & Polytrauma \\
\hline 9 & 44 & Male & MVA & Right & Open & $\mathrm{C} 2$ & OR \& K-wire & 16 & Isolated \\
\hline 10 & 21 & Male & MVA & Right & Open & B2 & OR \& K-wire & 15 & Polytrauma \\
\hline 11 & 28 & Male & MVA & Left & Closed & B1 & ORIF, screw \& K-wire & 23 & Polytrauma \\
\hline 12 & 21 & Male & MVA & Left & Closed & $\mathrm{C} 2$ & ORIF, screw \& K-wire & 25 & Isolated \\
\hline 13 & 25 & Male & MVA & Left & Closed & B2 & ORIF \& screw fix & 16 & Isolated \\
\hline 14 & 33 & Male & Industrial & Right & Closed & B2 & ORIF \& screw fix & 20 & Isolated \\
\hline 15 & 23 & Male & MVA & Left & Closed & B2 & OR \& K-wire & 18 & Isolated \\
\hline 16 & 22 & Male & Industrial & Right & Closed & A & CMR, p/c K-wire & 20 & Polytrauma \\
\hline 17 & 23 & Male & Industrial & Right & Open & $\mathrm{C} 2$ & OR \& K-wire & 23 & Isolated \\
\hline 18 & 29 & Male & Industrial & Right & Closed & $\mathrm{C} 2$ & CMR, p/c K-wire & 18 & Isolated \\
\hline 19 & 35 & Female & Fall & Left & Closed & B2 & CMR, p/c K-wire & 16 & Isolated \\
\hline 20 & 48 & Male & MVA & Left & Open & $\mathrm{C} 1$ & OR \& K-wire & 25 & Polytrauma \\
\hline 21 & 37 & Male & MVA & Left & Closed & $\mathrm{C} 1$ & OR \& K-wire & 20 & Isolated \\
\hline 22 & 21 & Male & Industrial & Right & Closed & A & CMR, p/c K-wire & 15 & Isolated \\
\hline 23 & 19 & Male & Fall & Right & Closed & B1 & OR \& K-wire & 16 & Polytrauma \\
\hline 24 & 23 & Male & MVA & Right & Open & $\mathrm{C} 2$ & OR \& K-wire & 24 & Polytrauma \\
\hline 25 & 28 & Male & MVA & Right & Open & $\mathrm{C} 2$ & OR \& K-wire & 23 & Isolated \\
\hline 26 & 28 & Male & MVA & Right & Closed & $\mathrm{C} 2$ & CMR, p/c K-wire & 16 & Polytrauma \\
\hline 27 & 20 & Male & Industrial & Left & Closed & B2 & ORIF \& screw fix & 18 & Polytrauma \\
\hline 28 & 34 & Male & MVA & Right & Closed & B2 & CMR, p/c K-wire & 20 & Polytrauma \\
\hline 29 & 34 & Male & Fall & Left & Closed & B2 & CMR, p/c K-wire & 25 & Isolated \\
\hline 30 & 22 & Male & MVA & Left & Closed & A & ORIF \& screw fix & 23 & Polytrauma \\
\hline 31 & 29 & Male & Industrial & Left & Closed & A & CMR, p/c K-wire & 15 & Isolated \\
\hline 32 & 32 & Male & MVA & Left & Open & B1 & OR \& K-wire & 16 & Isolated \\
\hline 33 & 36 & Male & MVA & Right & Closed & B2 & OR \& K-wire & 25 & Isolated \\
\hline 34 & 30 & Male & MVA & Right & Closed & $\mathrm{C} 1$ & OR \& K-wire & 24 & Polytrauma \\
\hline
\end{tabular}

MVA: Motor vehicle accident; ORIF: Open reduction internal fixation; CMR: Closed manipulative reduction; p/c: Percutaneous; OR: Open reduction. 


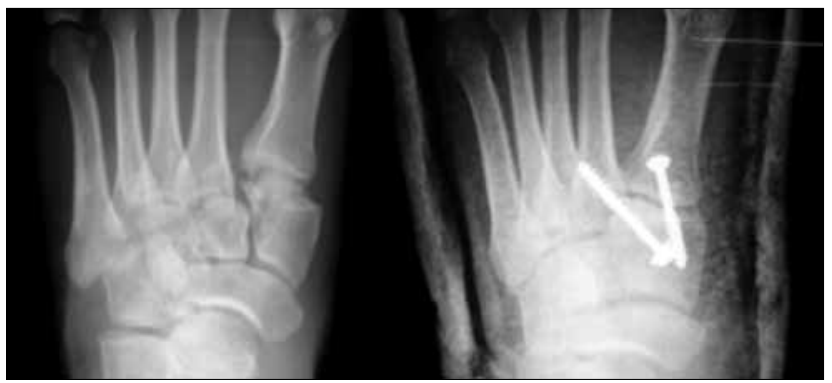

Fig. 2. Type B Lisfranc injury fixed with screw fixation. Type B: Pre and post reduction.

fixation. The majority of the patients (44\%) were treated with open reduction and K-wire fixation. In our series, an average of $2 \mathrm{~K}$-wires or 2 screws were used for the fixation. In unstable cases, a combination of 2 screws and $2 \mathrm{~K}$-wires was used. There were no cases of displacement of the Lisfranc injury as of the latest follow-up.

Functional outcome was assessed using the BFS. All patients assessed with BFS had a good score in all categories, with a total score ranging from 16 to 25 (scores ranging from 15 to 42 were considered as a good functional outcome). Details are shown in Table 3 . There was only one patient in our series with symptoms of osteoarthritis.

\section{DISCUSSION}

The etiology of Lisfranc injuries has changed over time. The commonest cause of Lisfranc injuries in our series was motor vehicle accident, followed by industrial accidents. These injuries are a result of direct crushing force or an indirect pronation force acting on a fixed forefoot in equines. The commonest type encountered in our center was type B2 (41\%), followed by type $\mathrm{C} 2(23 \%)$, type B1 (15\%), type A $(12 \%)$, and the least common, type $\mathrm{C} 1(9 \%)$. This is in contrast to a series reported by Aitken and Poulson, ${ }^{[5]}$ in which there was dorsolateral displacement of all five metatarsals, or the series reported by Wilppula, ${ }^{[9]}$ in which dorsolateral displacement of four lateral metatarsals was the commonest injury.

We treated the majority (76.5\%) of these injuries with reduction and $\mathrm{K}$-wiring either percutaneously or via the open method. None of our patients experienced any displacement of the reduction, and the method of fixation was adequate until healing occurred. We removed all the $\mathrm{K}$-wires at the postoperative eighth week. This is similar to the protocol used by Rajapakse. ${ }^{[10]}$ However, in his series, he also removed the screws after six months, which we did not do. This is in contrast to what has been reported by Aitken. ${ }^{[5]}$ In his series, he felt that temporary fixation with $\mathrm{K}$-wires was inadequate as it led to eventual displacement. Gaweda ${ }^{[11]}$ reported, in his series of 41 patients with acute and chronic Lisfranc injuries followed for 16 years, that the best results were achieved after closed reduction and percutaneous $\mathrm{K}$-wire fixation in acute cases. Teng et al. ${ }^{[12]}$ analyzed the gait of the injured foot and the control foot in cases of Lisfranc injury with anatomic reduction, and showed no significant difference in the parameters. Therefore, anatomic reduction of the Lisfranc injury is essential to restore normal function of the foot.

In our series, we did not encounter any major complication, such as vascular impairment, compartment syndrome, redisplacement of the Lisfranc injury postfixation, or skin complications. We had only one case that had immediate displacement after closed manual reduction and casting, which had to be fixed electively with closed K-wiring. Jeifreys ${ }^{[13]}$ reported in his series that osteoarthritis is almost an inevitable sequela of Lisfranc injury, and Hardcastle ${ }^{[1]}$ reported in his series an osteoarthritis rate of $30 \%$. We encountered only one patient with signs and symptoms of osteoarthritis in our series - a 44-year-old male who presented with an isolated open Lisfranc injury (type C2). His injury was fixed with open reduction and K-wiring. He developed symptoms of osteoarthritis 13 months after the surgery.

In our study, we used the Modified Hardcastle Classification to classify the Lisfranc injuries. Talari$\mathrm{Co}^{[14]}$ studied the interrater reliability of this classification and concluded that there is moderate interrater agreement among clinicians when using this scale for interpreting Lisfranc injuries. For the functional score, we used the BFS, which is a useful tool for evaluating the efficacy of interventions and for describing foot health within populations. The BFS was designed to produce a measure that quantifies, from the patient's rather than the clinician's perspective, the impact that foot problems has on their everyday life. This will enable the health services to provide more responsive and equitable care. It also displays good internal reliability, loading predominantly on a single factor that addresses the feet and perceived disability. The BFS provide a valuable additional contribution to professional foot-health status scores and potentially uncovers subtle psychological factors that influence behavior and outcomes. ${ }^{[7]}$ All the patients in our series scored within the range of good functional outcome (15-42) regardless of the fixation methods used or type of Lisfranc injury sustained.

In conclusion, all Lisfranc injuries treated in our center, regardless of the severity of the injury or method of treatment, demonstrated a good long-term functional outcome based on the BFS. We found that both $\mathrm{K}$-wire and screw fixation were adequate in achieving an acceptable anatomical reduction until the injury healing occurred. 


\section{REFERENCES}

1. Hardcastle PH, Reschauer R, Kutscha-Lissberg E, Schoffmann W. Injuries to the tarsometatarsal joint. Incidence, classification and treatment. J Bone Joint Surg [Br] 1982;64:34956.

2. Yuen JS, Yung SW, Wong MK. Open reduction and temporary rigid internal fixation of Lisfranc fracture-dislocations. Singapore Med J 2001;42:255-8.

3. Cassebaum WH. Lisfranc fracture-dislocations. Clin Orthop Relat Res 1963;30:116-29.

4. Wilson DW. Injuries of the tarso-metatarsal joints. Etiology, classification and results of treatment. J Bone Joint Surg [Br] 1972;54:677-86.

5. Aitken AP, Poulson D. Dislocations of the tarsometatarsal joint. J Bone Joint Surg [Am] 1963;45-A:246-60.

6. Wiley JJ. The mechanism of tarso-metatarsal joint injuries. J Bone Joint Surg Br 1971;53:474-82.

7. Myerson MS, Fisher RT, Burgess AR, Kenzora JE. Fracture dislocations of the tarsometatarsal joints: end results correlated with pathology and treatment. Foot Ankle 1986;6:22542.
8. Barnett S, Campbell R, Harvey I. The Bristol Foot Score: developing a patient-based foot-health measure. J Am Podiatr Med Assoc 2005;95:264-72.

9. Wilppula E. Tarsometatarsal fracture-dislocation. Late results in 26 patients. Acta Orthop Scand 1973;44:335-45.

10. Rajapakse B, Edwards A, Hong T. A single surgeon's experience of treatment of Lisfranc joint injuries. Injury 2006;37:914-21.

11. Gaweda K, Tarczyńska M, Modrzewski K, Turzańska K. An analysis of pathomorphic forms and diagnostic difficulties in tarso-metatarsal joint injuries. Int Orthop 2008;32:705-10.

12. Teng AL, Pinzur MS, Lomasney L, Mahoney L, Havey R. Functional outcome following anatomic restoration of tarsalmetatarsal fracture dislocation. Foot Ankle Int 2002;23:922-6.

13. Jeifreys TE. Lisfranc's fracture-dislocation: a clinical and experimental study of tarso-metatarsal dislocations and fracture-dislocations. J Bone Joint Surg [Br] I963:45:546-51.

14. Talarico RH, Hamilton GA, Ford LA, Rush SM. Fracture dislocations of the tarsometatarsal joints: Analysis of interrater reliability in using the modified Hardcastle classification system. J Foot Ankle Surg 2006;45:300-3. 